\title{
Factor V Activation and Inactivation by Venom Proteases
}

\author{
Jan Rosing José W.P. Govers-Riemslag Lev Yukelson \\ Guido Tans \\ Department of Biochemistry, Cardiovascular Research Institute Maastricht, \\ University of Maastricht, Maastricht, The Netherlands
}

\section{Key Words}

Venom · Snake venom · Caterpillar · Blood coagulation factor $\mathrm{V}$. Factor $\mathrm{V}$ activation .

Factor $\mathrm{V}$ inactivation

\begin{abstract}
Blood coagulation factor $\mathrm{V}$ is a single-chain glycoprotein with $M_{r}=330,000$ which plays an important role in the procoagulant and anticoagulant pathways. Thrombin activates factor $\mathrm{V}$ into factor $\mathrm{Va}$, a two-chain molecule which is composed of a heavy $\left(\mathrm{M}_{\mathrm{r}}=105,000\right)$ and a light chain $\left(\mathrm{M}_{\mathrm{r}}=71,000 / 74,000\right)$. Factor $\mathrm{Va}$ accelerates factor Xa-catalysed prothrombin activation more than 1,000-fold and under physiological conditions the cofactor activity of factor $\mathrm{Va}$ in prothrombin activation is down-regulated by activated protein C. Factor $\mathrm{V}$ can also be activated by a wide variety of snake venoms (e.g. from Vipera species, Naja naja oxiana, Bothrops atrox) and by
\end{abstract}

\begin{tabular}{ll}
\hline KARGER & ( ) 2002 S. Karger AG, Basel \\
Fax +41 61306 1234 & 0301-0147/01/0316-0241\$17.50/0 \\
$\begin{array}{l}\text { E-Mail karger@karger.ch } \\
\text { www.karger.com }\end{array}$ & $\begin{array}{l}\text { Accessible online at: } \\
\text { www.karger.com/journals/hae }\end{array}$
\end{tabular}

proteases present in the bristles of a South American caterpillar (Lonomia achelous). Some venoms, notably of Vipera lebetina turanica and Lonomia achelous, contain proteases that are able to inactivate factor $V$ or factor $V a$. Venom factor $V$ activators are excellent tools in studying the structure-function relationship of factor $\mathrm{V}(\mathrm{a})$ and they are also used in diagnostic tests for quantification of plasma factor $V$ levels and for the screening of defects in the protein $C$ pathway. In this review, the structural and functional properties of animal venom factor $V$ activators and inactivators is described.

Copyright $\odot 2002$ S. Karger AG, Basel

\section{Introduction}

For almost every clotting factor in the coagulation cascade there is a venom protease that can activate it. This paper focuses on ani-

Prof. Dr. J. Rosing, Department of Biochemistry

Cardiovascular Research Institute Maastricht, University of Maastricht PO Box 616, NL-6200 MD Maastricht (The Netherlands) Tel. +31 433881678 , Fax +31 433884159

E-Mail j.rosing@bioch.unimaas.nl 
Fig. 1. Schematic diagram of factor $\mathrm{V}$ activation.

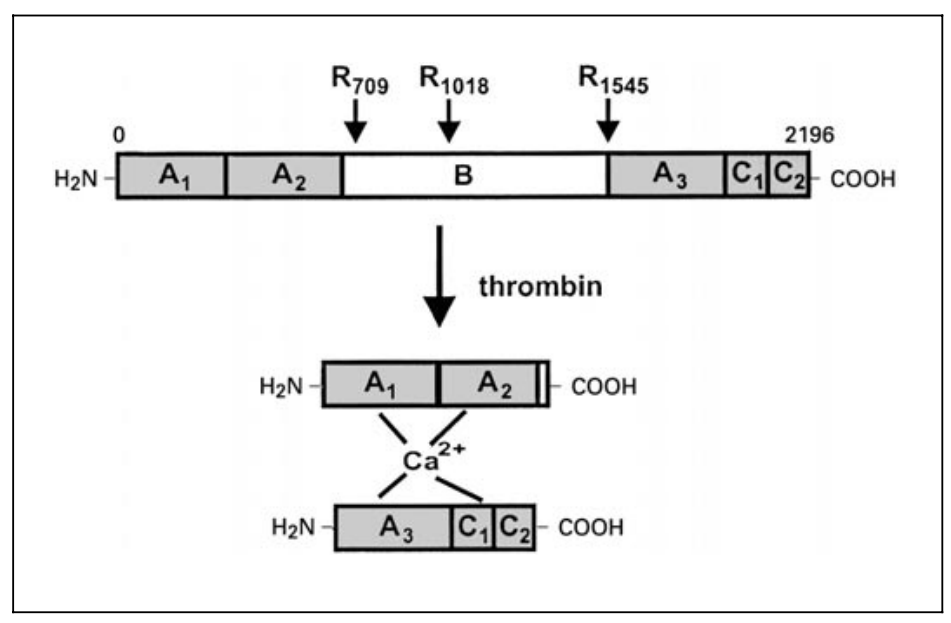

mal venom components that can activate or inactivate blood coagulation factor $\mathrm{V}$, a clotting factor which, considering its central position in the coagulation cascade, has a key function in haemostasis.

Factor $\mathrm{V}$ is a multi-functional protein which plays an important role in both the procoagulant and anticoagulant pathways [for reviews, see ref. 1, 2]. Factor V (fig. 1) circulates in plasma as a single-chain glycoprotein with a molecular mass of $330 \mathrm{kD}$. However, factor $\mathrm{V}$ is not active as a coagulation factor and in order to express procoagulant activity it has to be first activated by thrombin or factor Xa. Activation proceeds via specific cleavage of peptide bonds at positions 709, 1018 and 1545 , and yields factor $\mathrm{Va}$, a heterodimer consisting of a heavy chain of $105 \mathrm{kD}$ and a light-chain doublet of about 71/74 kD.

Factor Va acts as cofactor in factor Xacatalysed prothrombin activation and it enhances the rate of thrombin formation more than 1,000-fold. Kinetic analysis has shown that factor $\mathrm{Va}$ accelerates prothrombin activation by: (1) acting as a receptor that promotes the binding of factor $\mathrm{Xa}$ and prothrombin to procoagulant membranes and (2) by enhanc- ing the catalytic activity of factor Xa [2]. Factor $\mathrm{V}$ also plays a role in the anticoagulant pathway. Its cofactor activity in prothrombin activation is down-regulated by activated protein $\mathrm{C}$ and finally it has been shown that factor $\mathrm{V}$ acts as cofactor in activated protein C (APC)-mediated factor VIII inactivation $[1,2]$.

Animal venom proteins have been used as a tool in investigations of the structure-function relationship of factor $\mathrm{V}$ and in the development of diagnostic tests that probe the properties of factor $\mathrm{V}$ in both the pro- and anticoagulant pathways.

\section{Animal Venom Factor V Activators and Inactivators}

Table 1 summarises the animal venoms which have been reported to contain factor $\mathrm{V}$ activators. The venoms of Viperidae are historically linked with blood coagulation. Already around 1960 it was reported that Russel's viper venom contains both a potent factor X [3] and a factor V activator [4]. In 1978 it was shown that thrombocytin, the throm- 
Table 1. Animal venom factor $\mathrm{V}$ activators

\begin{tabular}{ll}
\hline Venom source & Species \\
\hline Bristles of larvae (caterpillar) of Lepidoptera & L. achelous \\
Venoms of Crotalidae & B. atrox (thrombocytin) \\
Venoms of Elapidae & N. n. oxiana \\
Venoms of Viperidae & V.russelli, V. lebetina, \\
& V.ursini \\
\hline
\end{tabular}

bin-like enzyme from Bothrops atrox was able to activate factor V [5] and in the early 1990s our laboratory in Maastricht reported that the venom of several Naja species contained a factor $\mathrm{V}$ activator [6]. Recently, it was shown that the bristles from certain South American caterpillars contain two different proteases that can activate and inactivate factor $\mathrm{V}$, respectively [7]. The venom factor $\mathrm{V}$ activator from Naja naja oxiana partially inactivates thrombin-activated factor V [6], and unpublished observations reported in the present paper indicate that the venom from Vipera lebetina turanica is also able to inactivate factor Va. In this paper we will provide further information on the structural and functional properties of the factor $\mathrm{V}$ activators and inactivators.

\section{Factor V Activators in Venoms from Viperidae}

Russel's viper venom contains a powerful factor $\mathrm{V}$ activator, which is called RVV-V. The ability to activate factor $\mathrm{V}$ was first recognized by Hjort [4] in 1957 and RVV-V was purified to homogeneity by Kisiel [8]. RVV-V is a single-chain serine protease which consists of 236 amino acids [9]. This enzyme activates factor $\mathrm{V}[10,11]$ by a specific cleavage of a single peptide bond at $\operatorname{Arg}^{1545}$ [12] which distinguishes it from thrombin which also cleaves factor V at positions 709 and 1018 .
The product obtained after activation by RVV-V does however have the same procoagulant activity as thrombin-activated factor $\mathrm{V}[10,11] . \mathrm{RVV}-\mathrm{V}$ is unique in that no other substrate has as yet been identified and it is widely used in research in the field of haemostasis and thrombosis.

The RVV-V purified by Kisiel [8] appeared to contain 3 isoproteins that could be separated by HPLC [9]. The three isoproteins called RVV-V $\alpha$, RVV-V $\beta$ and RVV-V $\gamma$, which are present in the purified preparation in a weight ratio $2: 1: 6$, have molecular masses of $29,27.5$ and $29 \mathrm{kD}$, respectively [9]. The amino acid composition of RVV-V $\beta$ differed from that of RVV-V $\alpha$ and RVV-V $\gamma$. Since only limited amounts of protein were available, RVV-V $\beta$ was not further characterised. The complete amino acid sequences of RVV$\mathrm{V} \alpha$ and $\mathrm{RVV}-\mathrm{V} \gamma$ were determined and both contained 236 amino acids and they differed in 6 amino acid residues [9]. It is not known whether RVV-V $\alpha, R V V-V \beta$ and RVV-V $\gamma$ exhibit the same activity in factor $\mathrm{V}$ activation since it was not possible to study their functional properties due to the fact that they were only separable by HPLC under denaturing conditions.

Other Vipera species also contain factor $\mathrm{V}$ activators. Siigur et al. [13, 14] characterised the activator from Vipera lebetina. In our laboratory [unpubl. obs.] we compared the factor $\mathrm{V}$ activators from Vipera russelli, $V$. lebetina and Vipera ursini called RVV-V, LVV-V and 
Fig. 2. SDS-PAGE analysis of factor $\mathrm{V}$ activators purified from the venoms of $V$. russelli (RVV), $V$. lebetina (LVV) and $V$. ursini (UVV). Molecular weight markers are indicated $\mathrm{M}_{\mathrm{r}}$.

Fig. 3. a, b Time courses of activation and inactivation of factor $\mathrm{V}$ by vipera activators. a Concentrations of activators were: $010 \mathrm{n} M$ $\mathrm{RVV}-\mathrm{V}, \boldsymbol{\square}=10 \mathrm{n} M$ LVV-V, $\boldsymbol{\Delta}=$ $9 \mathrm{n} M$ UVV-V and $\mathrm{O}=0.25 \mathrm{n} M$ human $\alpha$-thrombin. b Inactivation of factor Va by $250 \mathrm{n} M \mathrm{LVV}-\mathrm{V}$.
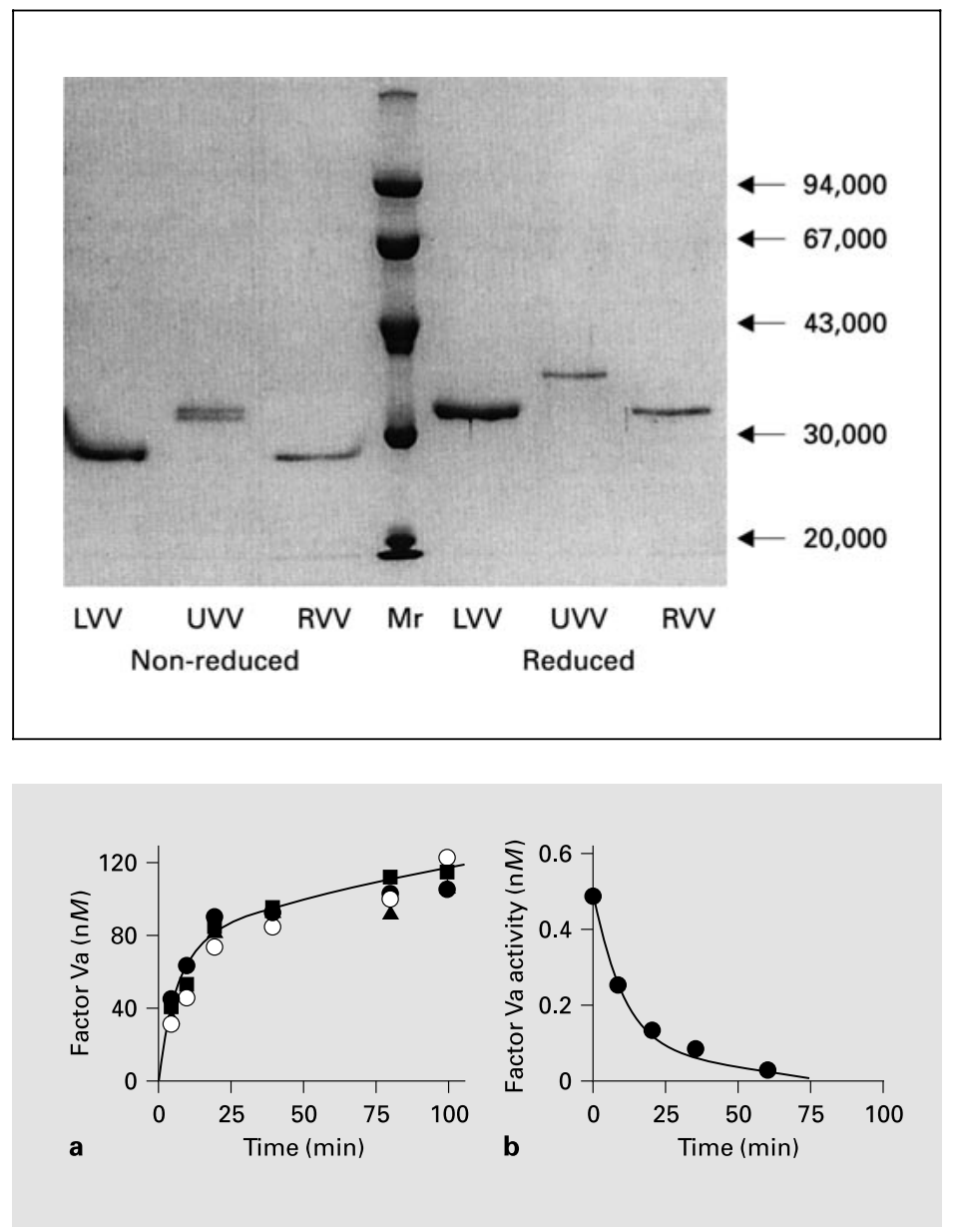

UVV-V, respectively. The activators were purified to homogeneity and had molecular weights of 29,000 in the case of $V$. lebetina and $V$. russelli and 34,000 in the case of $V$. ursini (fig. 2).

The three venom activators were equally active in activating factor $\mathrm{V}$ (fig. 3a). For comparison, the time course of factor $\mathrm{V}$ activation by thrombin is also given in this figure. It should be emphasised that the thrombin concentration in the activation mixture was some 40-fold lower than the concentration of the venom activators. This means that throm- bin is about 40 times more effective in activating factor $\mathrm{V}$ than the Vipera activators.

Finally, it was observed that the purified activator from $V$. lebetina (LVV-V) not only activated factor $\mathrm{V}$, but also inactivated factor Va. When thrombin- or venom-activated factor $\mathrm{V}$ was incubated with $250 \mathrm{n} M \mathrm{LVV}-\mathrm{V}$, the cofactor activity of factor $\mathrm{Va}$ in prothrombin activation was lost with a half-life of about $10 \mathrm{~min}$ (fig. 3b). Since the concentration of LVV-V used in this experiment was about 25 times higher than in the activation experiments, this means that under normal activa- 
tion conditions there is only a minor degradation of factor Va by LVV-V. Currently, we are investigating which peptide bond cleavages in factor $\mathrm{Va}$ are responsible for LVV-V-catalysed factor Va inactivation.

\section{Factor V Activator from the Venom of Naja naja oxiana}

During a screening of the pro- and anticoagulant properties of snake venoms from the Elapidae family it was observed that the venoms from several Naja species were able to activate factor $\mathrm{V}[6,15]$. The factor $\mathrm{V}$ activator present in the venom of $N$. n. oxiana, which contained the largest amount of activator, was purified by repeated chromatography on a Mono S column [6]. The purified activator appears to be a single-chain protein which, as judged by polyacrylamide gel electrophoresis in the presence of SDS, has an apparent molecular mass of $48 \mathrm{kD}$.

The $N$. n. oxiana protease activates factor $\mathrm{V}$ by cleaving two peptide bonds yielding a factor Va molecule which, compared with thrombin-activated factor $\mathrm{V}$, has a somewhat smaller heavy and larger light chain [6]. These small differences have a rather large effect on the cofactor activity of factor $\mathrm{Va}$ in prothrombin activation. N. n. oxiana-activated factor $\mathrm{V}$ had an 8-fold lower cofactor activity than thrombin-activated factor V. Addition of $N$. n. oxiana protease to thrombin activated-factor $\mathrm{V}$ resulted in some $90 \%$ loss of the cofactor activity of factor $\mathrm{Va}$ in prothrombin activation, indicating that the factor $\mathrm{V}$ activator from $N$. $n$. oxiana cleaves a peptide bond in both factor $\mathrm{V}$ and factor $\mathrm{Va}$ that results in the formation of a factor Va derivative which has a strongly diminished cofactor activity. SDSPAGE in combination with HPLC and amino acid sequencing of a peptide isolated from a venom-treated factor Va preparation indi- cated that the venom activator removed the last 27 amino acids from the carboxy terminal domain of the heavy chain of factor $\mathrm{Va}$ [16]. This indicates that the venom protease from Naja oxiana cleaves the $\mathrm{His}^{682}$-Asp ${ }^{683}$ peptide bond in factor V. Kinetic analysis showed that Naja oxiana-activated factor V had a diminished affinity for factor $\mathrm{Xa}$ and prothrombin [16], which indicates that the $\mathrm{Asp}^{683}{ }^{6} \mathrm{Arg}^{709}$ domain of factor $\mathrm{Va}$ is essential for optimal interaction with prothrombin and factor $\mathrm{Xa}$.

\section{Factor V Activators Present in the Venoms from Bothrops atrox and Lonomia achelous}

Thrombocytin, a protease isolated from the venom of Bothrops atrox by Niewiarowski et al. [17] and Kirby et al. [18], is also able to activate factor V [5]. Purified thrombocytin is a glycoprotein with a molecular mass of $36 \mathrm{kD}$ which is a thrombin-like serine protease which not only activates factor $\mathrm{V}$, but also platelets, factor XIII and factor VIII [17].

Activation of factor $\mathrm{V}$ by thrombocytin proceeds via the cleavage of two peptide bonds yielding a product which on the basis of SDS-PAGE is similar to thrombin-activated factor V [5]. The exact position of the peptide bonds in factor $\mathrm{V}$ that are cleaved by thrombocytin during activation is not yet known and there is also no information on the cofactor activity of thrombocytin-activated factor $\mathrm{V}$.

It is well known that contact with caterpillars of moths belonging to the genus Lonomia may cause a haemorrhagic syndrome that likely results from the presence of proteolytic proteins in the bristles of these caterpillars which affect coagulation and fibrinolysis [1921]. Lopez and Arocha-Pinango [7] identified a factor $\mathrm{V}$ activator in the hemolymph of $L$. achelous. The partially purified activator ap- 
pears to be a thermostable metalloprotease which has a molecular mass less than $97 \mathrm{kD}$. The crude venom also contains a high molecular mass serine or cysteine protease that inactivates factor V. Unfortunately, there is as yet no information on the peptide bonds that are cleaved in factor $\mathrm{V}$ during activation and inactivation by the proteases present in the venom of $L$. achelous.

\section{References}

1 Dahlback B: Procoagulant and anticoagulant properties of coagulation factor V: Factor V Leiden (APC resistance) causes hypercoagulability by dual mechanisms. J Lab Clin Med 1999;133:415-422.

2 Rosing J, Tans G: Coagulation factor V: An old star shines again. Thromb Haemost 1997;78:427433.

3 MacFarlane RG: The coagulant action of Russell's viper venom; the use of antivenom in defining its reaction with a serum factor. Br $\mathrm{J}$ Haematol 1961;7:496-511.

4 Hjort PF: Intermediate reactions in the coagulation of blood with tissue thromboplastin. Scand J Clin Lab Invest 1957;9:1-18.

5 Rawala R, Saraswati S, Niewiarowski S, Colman R: Molecular changes during the activation of bovine factor $\mathrm{V}$ by snake venom proteases (abstract). Circulation 1978;58:209.

6 Gerads I, Tans G, Yukelson L, Zwaal RF, Rosing J: Activation of bovine factor $\mathrm{V}$ by an activator purified from the venom of Naja naja oxiana. Toxicon 1992;30:10651079.

7 Lopez M, Gil A, Arocha-Pinango CL: The action of Lonomia achelous caterpillars venom on human factor V. Thromb Res 2000;98:103-110.

8 Kisiel W: Molecular properties of the factor $\mathrm{V}$-activating enzyme from Russell's viper venom. J Biol Chem 1979;254:12230-12234.
9 Tokunaga F, Nagasawa K, Tamura $\mathrm{S}$, Miyata $\mathrm{T}$, Iwanaga $\mathrm{S}$, Kisiel W: The factor $\mathrm{V}$-activating enzyme (RVV-V) from Russell's viper venom. Identification of isoproteins RVV-V alpha, -V beta, and -V gamma and their complete amino acid sequences. J Biol Chem 1988;263: 17471-17481.

10 Suzuki K, Dahlback B, Stenflo J: Thrombin-catalyzed activation of human coagulation factor V. J Biol Chem 1982;257:6556-6564.

11 Kane WH, Majerus PW: Purification and characterization of human coagulation factor V. J Biol Chem 1981;256:1002-1007.

12 Kane WH, Davie EW: Blood coagulation factors V and VIII: Structural and functional similarities and their relationship to hemorrhagic and thrombotic disorders. Blood 1988; 71:539-555.

13 Siigur E, Aaspollu A, Siigur J: Molecular cloning and sequence analysis of a cDNA for factor $V$ activating enzyme. Biochem Biophys Res Commun 1999;262:328-332.

14 Siigur E, Samel M, Tonismagi K, Subbi J, Reintamm T, Siigur J: Isolation, properties and N-terminal amino acid sequence of a factor $\mathrm{V}$ activator from Vipera lebetina (Levantine viper) snake venom. Biochim Biophys Acta 1998;1429:239248.

15 Yukelson LY, Tans G, Thomassen MC, Hemker HC, Rosing J: Procoagulant activities in venoms from central Asian snakes. Toxicon 1991; 29:491-502.
16 Bakker HM, Tans G, Thomassen MC, Yukelson LY, Ebberink R, Hemker HC, Rosing J: Functional properties of human factor Va lacking the Asp683-Arg709 domain of the heavy chain. J Biol Chem 1994; 269:20662-20667.

17 Niewiarowski S, Kirby EP, Brudzynski TM, Stocker K: Thrombocytin, a serine protease from Bothrops atrox venom. 2. Interaction with platelets and plasma-clotting factors. Biochemistry 1979;18:35703577.

18 Kirby EP, Niewiarowski S, Stocker K, Kettner C, Shaw E, Brudzynski TM: Thrombocytin, a serine protease from Bothrops atrox venom. 1. Purification and characterization of the enzyme. Biochemistry $1979 ; 18$ : 3564-3570.

19 Arocha-Pinango CL, Marval E, Guerrero B: Lonomia genus caterpillar toxins: Biochemical aspects. Biochimie 2000;82:937-942.

20 Amarant T, Burkhart W, LeVine H, 3rd, Arocha-Pinango CL, Parikh I: Isolation and complete amino acid sequence of two fibrinolytic proteinases from the toxic Saturnid caterpillar Lonomia achelous. Biochim Biophys Acta 1991;1079:214-221.

21 Donato JL, Moreno RA, Hyslop S, Duarte A, Antunes E, Le Bonniec BF, Rendu F, de Nucci G: Lonomia obliqua caterpillar spicules trigger human blood coagulation via activation of factor $\mathrm{X}$ and prothrombin. Thromb Haemost 1998;79:539_ 542. 